\title{
Hydroboration of Terminal Alkynes Catalysed by Sodium Triethylborohydride
}

\author{
Anna M. Maja,b, Piotr Pawlućc,c, Maciej Zaranek ${ }^{\mathrm{b}, \mathrm{c}, *}$
}

\begin{abstract}
${ }^{a}$ Faculty of Chemical Technology and Engineering, University of Technology and Life Sciences in Bydgoszcz, Seminaryjna St. 3, 85-326 Bydgoszcz, Poland

${ }^{b}$ Centre for Advanced Technologies, Adam Mickiewicz University, Uniwersytetu Poznańskiego St. 10, 61-614 Poznań, Poland

c Faculty of Chemistry, Adam Mickiewicz University, Uniwersytetu Poznańskiego St. 8, 61-614 Poznań, Poland

*m.zaranek@amu.edu.pl
\end{abstract}

\begin{abstract}
Sodium triethylborohydride - commonly used as a reducing agent for hydroboration catalysts based on the first-row transition metal complexes with tridentate ligands, has been found a highly selective catalyst for hydroboration of terminal alkynes. Hydroboration of aromatic and aliphatic alkynes with pinacolborane in the presence of $10 \mathrm{~mol}_{\%}$ of $\mathrm{NaHBEt}_{3}$ proceeded in a highly selective manner to give $(E)$-vinylboronate esters with high yields, whereas ethynylsilanes seem to be less reactive in this process.
\end{abstract}

Keywords: hydroboration, alkynes, transition-metal-free, borohydrides

\section{Introduction}

Vinylboronates play a pivotal role in modern organic synthesis as essential synthons in selective carbon-carbon or carbon-heteroatom bond formation reactions which are important especially in the pharmaceutical, agrochemical and cosmetic industries. [1] Catalytic hydroboration of alkynes with hydroborates is a powerful tool for generating vinylboronates (Scheme 1) and this transformation usually occurs via syn-addition of a B-H moiety to yield (E)-vinylboronate esters.[2] Recently, a new generation of catalysts for selective alkyne hydroboration was reported. They were based on earthabundant first- row transition metal complexes with tridentate nitrogen-containing ligands and have attracted considerable attention. [3],[4] These bench-stable precatalysts required activation, usually using alkali metal trialkylborohydrides, to achieve high catalytic activity. [3]

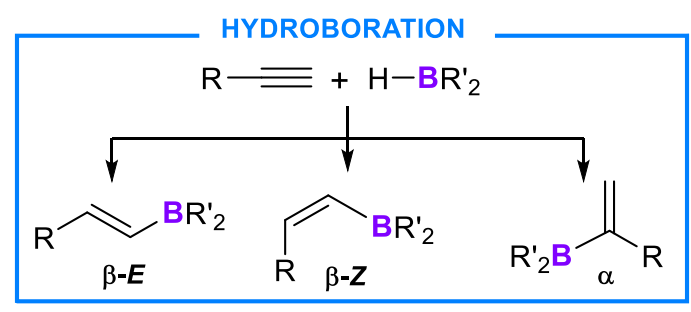

Scheme 1. Theoretically possible products of hydroboration of terminal alkynes.

Hydroboration of terminal and internal alkynes has been also successful using transition metal-free, boron-containing catalysts (e.g. $\quad \mathrm{B}\left(\mathrm{C}_{6} \mathrm{~F}_{5}\right)_{3}$, borenium cations, $\mathrm{HB}\left(\mathrm{C}_{6} \mathrm{~F}_{5}\right)_{2}$, tris[3,5bis(trifluoromethyl)phenyl]borane, tris(2,4,6-trifluorophenyl)borane, $\left.\mathrm{H}_{3} \mathrm{~B} \cdot \mathrm{THF}\right)$ [5],[6],[7],[8],[9],[10] 
however, to the best of our knowledge, there is only a single report on the use of commercially available sodium triethylborohydride in this process. [9] $\mathrm{NaHBEt}_{3}$ has been demonstrated by Thomas and coworkers to catalyse hydroboration of phenylacetylene with pinacolborane to give $(E)$-styryl boronic ester in $45 \%$ yield.[9]

We have already reported that $\mathrm{NaHBEt}_{3}$ can be used as a selective catalyst for dehydrogenative silylation of alkynes with hydrosilanes [11] and Markovnikov-selective hydrosilylation of alkenes.[12],[13] Given the preliminary report from the Thomas group and the mechanistic similarity of hydrosilylation and hydroboration reactions, we decided to study in more detail the reactivity of terminal alkynes and pinacolborane in the presence of alkali metal triethylborohydrides in order to examine the impact of these commonly used reductants on the course of the hydroboration process.

\section{Methods}

\section{General remarks}

All reactions were performed in an oven-dried glassware under the argon atmosphere. Solvents were dried by distillation over sodium/benzophenone. Alkynes and pinacolborane were used as supplied and degassed prior to use. Alkali metal trialkylborohydrides were commercially available as $1 \mathrm{M}$ solutions in toluene or THF and used as received. Gas chromatography was performed on a Bruker Scion 436GC with a TCD detector. GC-MS analyses were performed on a Bruker Scion 436-GC a Scion SQ-MS mass spectrometry detector. NMR analyses were performed on a Bruker Fourier 300 spectrometer and referenced to the solvent residual peak.

\section{General procedure of NaHBEt $t_{3}$-catalysed hydroboration}

$1.0 \mathrm{mmol}$ of alkyne, $0.1 \mathrm{~mL}$ of decane and $1.1 \mathrm{mmol}$ of pinacolborane, were placed in previously evacuated Schlenk bomb flask fitted with a plug valve. A reference sample was taken. Next, $0.1 \mathrm{~mL}$ of $1 \mathrm{M}$ solution of $\mathrm{NaHBEt}_{3}(0.1 \mathrm{mmol})$ in toluene was added, reaction vessel was closed and heated at $60{ }^{\circ} \mathrm{C}$ with stirring. After specified time, reaction mixture was cooled down to the room temperature and analysed using GC and GC-MS. Products of hydroboration were isolated by extraction with $1 \mathrm{~mL}$ of DCM followed by column chromatography of concentrated extract $\left(\mathrm{SiO}_{2}\right.$, hexane/Et $\left.{ }_{2} \mathrm{O}, 98: 2\right)$.

\section{Identification of selected hydroboration products}<smiles>CC1(C)OB(/C=C/c2ccccc2)OC1(C)C</smiles>

(E)-4,4,5,5-tetramethyl-2-styryl-1,3,2-dioxaborolane:

${ }^{1} \mathbf{H}$ NMR $\left(300 \mathrm{MHz}, \mathrm{CDCl}_{3}\right): \delta[\mathrm{ppm}] 1.25(\mathrm{~s}, 12 \mathrm{H}), 6.10(\mathrm{~d}, 1 \mathrm{H}, J=18.43 \mathrm{~Hz}), 7.24(\mathrm{~m}$ 4H), $\left.7.40(\mathrm{~m}, 2 \mathrm{H}) ;{ }^{13} \mathbf{C ~ N M R ~ ( 7 5 ~ M H z , ~} \mathrm{CDCl}_{3}\right): \delta[\mathrm{ppm}] 24.99,55.34,83.22,113.90$, $128.38,130.30,133.50,148.94,159.66 ;{ }^{11} \mathbf{B}$ NMR $\left(128 \mathrm{MHz}, \mathrm{CDCl}_{3}\right): \delta[\mathrm{ppm}] 30.11$; MS (EI, $70 \mathrm{eV}): \mathrm{m} / \mathrm{z}(\%): 183$ (100), 105 (20), 184 (16), 181 (16)

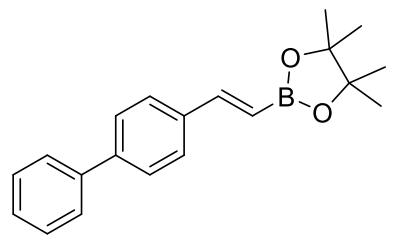

(E)-2-(2-([1,1'-biphenyl]-4-yl)vinyl)-4,4,5,5-tetramethyl-1,3,2-dioxaborolane:

${ }^{1} \mathbf{H}$ NMR $\left(300 \mathrm{MHz}, \mathrm{CDCl}_{3}\right): \delta[\mathrm{ppm}] 1.35(\mathrm{~s}, 12 \mathrm{H}), 6.25(\mathrm{~d}, 1 \mathrm{H}, J=18.42 \mathrm{~Hz})$, $7.38(\mathrm{~m}, 2 \mathrm{H}), 7.45(\mathrm{~m}, 1 \mathrm{H}), 7.61(\mathrm{~m}, 6 \mathrm{H}) ;{ }^{13} \mathbf{C}$ NMR $\left(75 \mathrm{MHz}, \mathrm{CDCl}_{3}\right): \delta[\mathrm{ppm}]$ $144.45,135.84,135.69,133.14,129.84129 .71,128.30,128.05,127.84,125.05$, 27.09, 16.63; MS (EI, $70 \mathrm{eV}): \mathrm{m} / \mathrm{z}(\%): 183$ (100), 105 (20), 184 (16), 181 (16) 
<smiles>COc1ccc2cc(/C=C/B3OC(C)(C)C(C)(C)O3)ccc2c1</smiles>

(E)-2-(2-(6-methoxynaphthalen-2-yl)vinyl)-4,4,5,5-tetramethyl-1,3,2-

dioxaborolane:

${ }^{1} \mathbf{H}$ NMR $\left(300 \mathrm{MHz}, \mathrm{CDCl}_{3}\right): \delta[\mathrm{ppm}] 1.36(\mathrm{~s}, 12 \mathrm{H}), 3.95(\mathrm{~s}, 3 \mathrm{H}), 6.25(\mathrm{~d}, 1 \mathrm{H}$, $J=18.39 \mathrm{~Hz}), 7.14(\mathrm{~m}, 2 \mathrm{H}), 7.56(\mathrm{~d}, 1 \mathrm{H}), 7.74(\mathrm{~m}, 4 \mathrm{H}) ;{ }^{13} \mathbf{C} \mathbf{N M R}(75 \mathrm{MHz}$, $\left.\mathrm{CDCl}_{3}\right): \delta[\mathrm{ppm}] 24.84,55.35,83.32,105.88,119.02,124.04,127.09,127.86$, 128.82, 129.95, 132.98, 135.01, 149.66, 158.14; ${ }^{11} \mathbf{B}$ NMR (128 MHz, $\left.\mathrm{CDCl}_{3}\right): \delta[\mathrm{ppm}] 30.33 ; \mathrm{MS}(\mathrm{EI}, 70 \mathrm{eV})$ : $\mathrm{m} / \mathrm{z}(\%): 183$ (100), $105(20), 184(16), 181(16)$<smiles></smiles>

(E)-2-(4-methoxystyryl)-4,4,5,5-tetramethyl-1,3,2-dioxaborolane:

${ }^{1} \mathbf{H}$ NMR $\left(300 \mathrm{MHz}, \mathrm{CDCl}_{3}\right): \delta[\mathrm{ppm}] 1.33(\mathrm{~s}, 12 \mathrm{H}), 3.84(\mathrm{~s}, 3 \mathrm{H}), 6.06(\mathrm{~d}, 1 \mathrm{H}, J=$ $15.00 \mathrm{~Hz}), 6.89(\mathrm{~d}, 2 \mathrm{H}), 7.42(\mathrm{~d}, 2 \mathrm{H}) ;{ }^{13} \mathbf{C} \mathbf{~ N M R}\left(75 \mathrm{MHz}, \mathrm{CDCl}_{3}\right): \delta[\mathrm{ppm}] 24.99$, $55.34,83.22,113.90,128.38,130.30,133.50,148.94,159.66$; MS (EI, $70 \mathrm{eV}): \mathrm{m} / \mathrm{z}$ (\%): 183 (100), 105 (20), $184(16), 181$ (16)

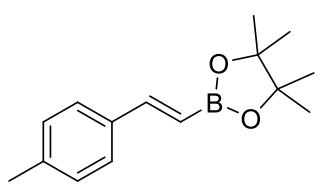

(E)-4,4,5,5-tetramethyl-2-(4-methylstyryl)-1,3,2-dioxaborolane:

${ }^{1} \mathbf{H}$ NMR $\left(300 \mathrm{MHz}, \mathrm{CDCl}_{3}\right): \delta[\mathrm{ppm}] 1.34(\mathrm{~s}, 12 \mathrm{H}), 2.37$ (s, 3H), $6.14(\mathrm{~d}, 1 \mathrm{H}, J=18.47$ $\mathrm{Hz}), 7.16(\mathrm{~m}, 2 \mathrm{H}), 7.40(\mathrm{~m}, 2 \mathrm{H}) ;{ }^{13} \mathbf{C} \mathbf{N M R}\left(75 \mathrm{MHz}, \mathrm{CDCl}_{3}\right): \delta[\mathrm{ppm}] 144.45,135.84$, 135.69, 133.14, $129.84129 .71,128.30,128.05,127.84,125.05,27.09,16.63$; MS (EI, $70 \mathrm{eV}): \mathrm{m} / \mathrm{z}(\%): 183$ (100), 105 (20), 184 (16), 181 (16)

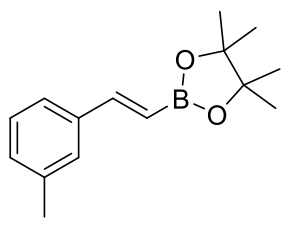

(E)-4,4,5,5-tetramethyl-2-(3-methylstyryl)-1,3,2-dioxaborolane:

${ }^{1} \mathbf{H}$ NMR $\left(300 \mathrm{MHz}, \mathrm{CDCl}_{3}\right): \delta[\mathrm{ppm}] 1.34(\mathrm{~s}, 12 \mathrm{H}), 2.37$ (s, 3H), $6.18(\mathrm{~d}, 1 \mathrm{H}, J=18.43$ $\mathrm{Hz}), 7.13(\mathrm{~m}, 1 \mathrm{H}), 7.28(\mathrm{~m}, 3 \mathrm{H}), 7.47(\mathrm{~m}, 1 \mathrm{H}) ;{ }^{13} \mathbf{C} \mathbf{~ N M R}\left(75 \mathrm{MHz}, \mathrm{CDCl}_{3}\right): \delta[\mathrm{ppm}]$ $21.40,24.94,83.31,124.24,127.78,128.45,129.70,137.60$, 138.24, 149.67; ${ }^{11} \mathbf{B}$ NMR $\left(128 \mathrm{MHz}, \mathrm{CDCl}_{3}\right): \delta[\mathrm{ppm}] 30.29 ; \mathbf{M S}(\mathrm{EI}, 70 \mathrm{eV}): \mathrm{m} / \mathrm{z}(\%)$ : 183 (100), 105 (20), 184 (16), 181 (16)

\section{Results and discussion}

We began our study with hydroboration of phenylacetylene (1) with 1.1 eq. of 4,4,5,5-tetramethyl-1,3,2dioxaborolane (pinacolborane, HBpin) using sodium triethylborohydride as a catalyst and without any additional solvent. It has to be noted, however, that all the borohydrides were supplied and used as $1 \mathrm{M}$ solutions in either toluene or THF. The results of the reaction conditions screening are presented in Table 1.

A portion of $10 \mathrm{~mol} \%$ of $\mathrm{NaHBEt}_{3}(1 \mathrm{M}$ in toluene) applied in the model reaction led to $71 \%$ conversion of 1 after $1 \mathrm{~h}$ at $60{ }^{\circ} \mathrm{C}$, and yielded exclusively monoborylated linear $(E)$-alkenyl boronate ester 2 (entry 7). The prolonged reaction time of $24 \mathrm{~h}$ gave higher conversion of $\mathbf{1}$ (93\%, entry 6). Increasing the reaction temperature to $80{ }^{\circ} \mathrm{C}$ resulted in complete conversion of $\mathbf{1}$ within $1 \mathrm{~h}$ affording product $\mathbf{2}$ with as high anti-Markovnikov regioselectivity as previously (>99\%, entry 5). Decreasing the catalyst loading to $5 \mathrm{~mol} \%$ of $\mathrm{NaHBEt}_{3}$ resulted in a decrease in reactivity: after $1 \mathrm{~h}$ at $80{ }^{\circ} \mathrm{C}$, only $87 \%$ conversion of $\mathbf{1}$ was observed (entry 4). The reactions carried out with an addition of solvents, such as toluene, THF or dioxane, led to lower conversions of 1 (83-85\%) (entries 10-12). Interestingly, two additional experiments performed with 2.2 equivalents of HBpin, with and without addition of toluene, both led to drastic reduction of phenylacetylene conversion and formation of two by-products: the alkyl boronate ester 3 and alkyl bisboronate ester 4 (entries 13-14).

Table 1. Screening of the reaction conditions 


\begin{tabular}{llllll}
\hline & & & \\
\hline \\
1
\end{tabular}

${ }^{\mathrm{a}}$ Determined by GC using $0.1 \mathrm{~mL}$ of decane as a reference; ${ }^{\mathrm{b}}$ Determined by GC-MS and ${ }^{1} \mathrm{H}$ NMR; ${ }^{\mathrm{c}}$ $1.0 \mathrm{mmol}$ of phenylacetylene and $2.2 \mathrm{mmol}$ of HBpin used.

Next, using the optimised reaction conditions as established above (entry 5), we examined the capabilities of other commercially available alkali metal trialkylborohydrides in catalysing hydroboration of phenylacetylene. All of the other borohydrides, i.e. $\mathrm{NaHB}(s-\mathrm{Bu})_{3}, \mathrm{LiHBEt}_{3}$ and $\mathrm{KHBEt}_{3}$, led to very high anti-Markovnikov regioselectivity of $97-99 \%$ of the $(E)$ isomer. Nevertheless, $\mathrm{NaHBEt}_{3}$ turned out to be the most active catalyst, as conversions of $\mathbf{1}$ reached with the other borohydrides did not go over $90 \%$ for $\mathrm{LiHBEt}_{3}$ and were even smaller for $\mathrm{NaHB}(s-\mathrm{Bu})_{3}(61 \%)$ and $\mathrm{KHBEt}_{3}(36 \%)$. Moreover, in the case of $\mathrm{LiHBEt}_{3}$ and $\mathrm{KHBEt}_{3}$, the GC-MS analysis showed that the alkyl bisboronate ester 4 was present as a by-product in small quantity $(<2 \%)$.

Having established the most optimal conditions, we attempted at extending the substrate scope over substituted phenylacetylene derivatives and other aromatic and aliphatic terminal alkynes.

Table 2 summarises the study of the influence of various types of substituents at the ethynyl moiety on its conversion and selectivity towards the desired product. Phenylacetylenes decorated with a methyl substituent located at the aryl group were converted with excellent anti-Markovnikov regioselectivity $(>99 \%)$ to linear $(E)$-alkenyl pinacol boronic esters. However the conversions after $1 \mathrm{~h}$ were rather moderate (59-75\%). As expected, the steric hindrance influences the reaction rate and 4-ethynyltoluene 
reacted faster than 3 - and 2-ethynyltoluene ( $75 \%$ vs $61 \%$ vs $59 \%$ conversion, entries $2-4$ ). When using 4-ethynyltoluene, extending reaction time to $24 \mathrm{~h}$ allowed for a nearly complete conversion of the alkyne. Phenylacetylene bearing electron-withdrawing bromo substituent underwent hydroboration by HBpin without any loss of regioselectivity, but with a moderate conversion of only $35 \%$ after $1 \mathrm{~h}$ (entry 6). The phenylacetylene derivatives with either a phenyl (entry 10) or a methoxy (entry 7) group at para position did also react much slower, giving only $40 \%$ and $68 \%$ of conversion, respectively. In both these cases, an extension of the reaction time $24 \mathrm{~h}$ increased the conversions to $87 \%$ and $99 \%$, respectively. On the other hand, weakly electron-donating $p$-tert-butyl group did not affect the reactivity of the phenylacetylene derivative (entry 5).

Table 2. Hydroboration of terminal alkynes.

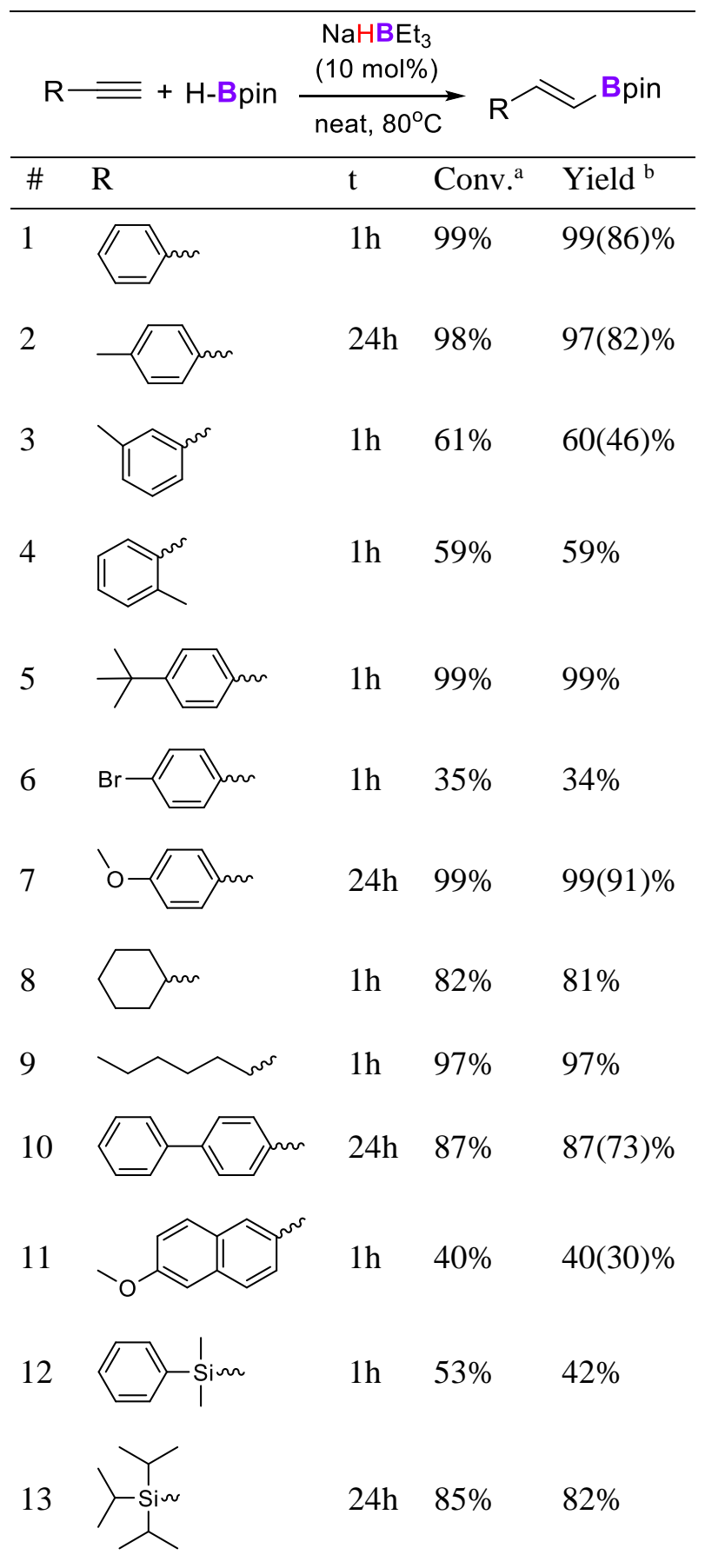

${ }^{\mathrm{a}}$ Determined by GC; ${ }^{\mathrm{b}} \mathrm{GC}$ yield, isolated yields are given in parentheses. 
Aliphatic alkynes were also successfully converted into adequate pinacol boronic esters. Similarly, an excellent anti-Markovnikov regioselectivity was observed, however, the alkyl substitution had a small negative effect on the catalyst activity, as the conversions were slightly lower. We then turned our attention to ethynylsilanes as another group of substrates whose hydroboration could possibly lead to potent building blocks - (E)-1-silyl-2-borylethenes. We carried out hydroboration of ethynyldimethyl(phenyl)silane (entry 12) and ethynyltriisopropylsilane (entry 13) with pinacolborane in the presence of $\mathrm{NaHBEt}_{3}$ (1M in toluene) as a catalyst. As it turned out, hydroboration of ethynylsilanes was not as effective as that of previous alkynes. The reaction with ethynyldimethyl(phenyl)silane resulted in moderate conversion of the substrate giving the corresponding product with only $80 \%$ of regioselectivity towards the linear ester. A higher regioselectivity of $>99 \%$ was observed with the use of ethynyltriisopropylsilane, however, the conversion was sill moderate. Noteworthy, trimethylsilylacetylene did not react at all. Representative examples of hydroboration products were isolated and analysed.

\section{Conclusions}

Sodium triethylborohydride turned out to catalyse regioselective hydroboration of aromatic and aliphatic terminal alkynes with pinacolborane. The conditions for this reaction were optimised and applied to synthesis of a group of (E)-1-boryl-2-alkyl- and (E)-1-boryl-2-arylethenes Although, the catalytic activity of $\mathrm{NaHBEt}_{3}$ can be moderate, alkali metal trialkylborohydrides, which are often used as activators of transition-metal-based catalytic systems, can exert direct influence on the hydroboration pathway. It should be emphasised that each their further use in this role should be preceded by careful consideration of possible influence on actual processes under study.

\section{Acknowledgements}

This work was financially supported by the National Science Centre, Poland (NCN), grant № UMO2016/23/B/ST5/00177.

\section{References}

[1] C. Torborg, M. Beller, Recent applications of palladium-catalyzed coupling reactions in the pharmaceutical, agrochemical, and fine chemical industries, Adv. Synth. Catal. 351 (2009) 3027-3043. https://doi.org/10.1002/adsc.200900587.

[2] R. Barbeyron, E. Benedetti, J. Cossy, J.J. Vasseur, S. Arseniyadis, M. Smietana, Recent developments in alkyne borylations, Tetrahedron. 70 (2014) 8431-8452. https://doi.org/10.1016/j.tet.2014.06.026.

[3] J. Chen, J. Guo, Z. Lu, Recent Advances in Hydrometallation of Alkenes and Alkynes via the First Row Transition Metal Catalysis, Chinese J. Chem. 36 (2018) 1075-1109. https://doi.org/10.1002/cjoc.201800314.

[4] H. Yoshida, Borylation of Alkynes under Base/Coinage Metal Catalysis: Some Recent Developments, ACS Catal. 6 (2016) 1799-1811. https://doi.org/10.1021/acscatal.5b02973.

[5] M. Fleige, J. Möbus, T. Vom Stein, F. Glorius, D.W. Stephan, Lewis acid catalysis: Catalytic hydroboration of alkynes initiated by Piers' borane, Chem. Commun. 52 (2016) 10830-10833. https://doi.org/10.1039/c6cc05360b.

[6] J.R. Lawson, L.C. Wilkins, R.L. Melen, Tris(2,4,6-trifluorophenyl)borane: An Efficient Hydroboration Catalyst, Chem. - A Eur. J. 23 (2017) 10997-11000. 
https://doi.org/10.1002/chem.201703109.

[7] J.R. Lawson, R.L. Melen, Tris(pentafluorophenyl)borane and Beyond: Modern Advances in Borylation Chemistry, Inorg. Chem. 56 (2017) 8627-8643. https://doi.org/10.1021/acs.inorgchem.6b02911.

[8] Q. Yin, S. Kemper, H.F.T. Klare, M. Oestreich, Boron Lewis Acid-Catalyzed Hydroboration of Alkenes with Pinacolborane: B ArF3Does What B(C6F5)3Cannot Do!, Chem. - A Eur. J. 22 (2016) 13840-13844. https://doi.org/10.1002/chem.201603466.

[9] N.W.J. Ang, C.S. Buettner, S. Docherty, A. Bismuto, J.R. Carney, J.H. Docherty, M.J. Cowley, S.P. Thomas, Borane-Catalysed Hydroboration of Alkynes and Alkenes, Synth. 50 (2018) 803808. https://doi.org/10.1055/s-0036-1591719.

[10] J.S. McGough, S.M. Butler, I.A. Cade, M.J. Ingleson, Highly selective catalytic: Trans hydroboration of alkynes mediated by borenium cations and B(C6F5)3, Chem. Sci. 7 (2016) 3384-3389. https://doi.org/10.1039/c5sc04798f.

[11] M. Skrodzki, S. Witomska, P. Pawluć, Sodium triethylborohydride as a catalyst for the dehydrogenative silylation of terminal alkynes with hydrosilanes, Dalt. Trans. 47 (2018). https://doi.org/10.1039/c8dt00684a.

[12] M. Zaranek, S. Witomska, V. Patroniak, P. Pawluć, Unexpected catalytic activity of simple triethylborohydrides in the hydrosilylation of alkenes, Chem. Commun. 53 (2017) 5404-5407. https://doi.org/10.1039/c7cc01531c.

[13] M. Nowicki, M. Zaranek, P. Pawluć, M. Hoffmann, DFT study of trialkylborohydridecatalysed hydrosilylation of alkenes-the mechanism and its implications, Catal. Sci. Technol. 10 (2020) 1066-1072. https://doi.org/10.1039/c9cy02261a. 